\title{
EFISIENSI RUTE PADA ROUTING AODV MENGGUNAKAN ALGORITMA PATH AWARE SHORT
}

\author{
Saiful Hamim ${ }^{1)}$ Misbah, Nuniek Fahriani \\ 1) Prodi Teknik Informatika Universitas Muhammadiyah Gresik \\ Fakultas Teknik,Universitas Muhammadiyah Gresik \\ Saifulhamim6@gmail.com
}

\begin{abstract}
INTISARI
Node-node pada MANET dapat berhubungan satu sama lain apabila mereka berada pada jangkauan transmisinya. Apabila bergerak menjauh diluar jangkauan transmisi maka link antara dua buah node dapat terputus pada saat proses pengiriman route request (RREQ). Dengan terputusnya suatu link, maka akan menyebabkan terputusnya sebuah rute yang ada dan juga dengan terputusnya link tertentu menyebabkan proses route discovery perlu dilakukan kembali sehingga mobilitas pada node merupakan masalah yang perlu untuk diperhatikan apabila ingin membentuk jaringan yang stabil. Efisiensi rute pada routing AODV menggunakan algoritma path aware short dengan parameter average End-to-end delay, energy, dan packet delivery ratio (PDR). efisiensi rute menggunakan path aware short mengalami keberhasilan dengan parameter average end to end delay untuk 100 node dengan network area $500 \mathrm{~m}^{2}$ x $500 \mathrm{~m}^{2}$ yaitu 5,1087 m/s. Karena selang waktu yang dibutuhkan lebih pendek dan tidak membebani link (kemungkinan kecil terputus). Dampak yang didapat dari efisiensi delay mengakibatkan semakin banyak paket RREQ yang dikirim, mengakibatkan peluang tabrakan antar paket semakin besar, menyebabkan hilangnya paket data yang drop, dikarenakan node pengirim akan lebih banyak melakukan broadcast paket routing pada proses route discovery (RREQ dan RREP) untuk mendapatkan rute yang baru. Dapat dilihat pada parameter packet delivery ratio nilai terbaik pada routing AODV dengan 50 node area 500x500, 100 node area 500x500, 50 node area 1000x1000 dengan nilai 100\%. Sedangkan Untuk parameter energy yang sedikit dalam konsumsi energy yaitu pada protokol routing AODV dengan 100 node area 1000x1500 dengan nilai 10,7794 joule.
\end{abstract}

Kata Kunci : Path Aware Short, AODV, MANET, NS 2, Efisiensi Rute.

\section{Pendahuluan}

\subsection{Latar Belakang}

Topologi network yang terus berubah, power transmisi yang rendah dan bandwidth rendah menjadi tantangan utama dalam pengaturan rute. Salah satu protokol routing yang melakukan proses pencarian rute dengan rentan waktu yang cukup lama pada jaringan MANET adalah routing protokol Ad Hoc OnDemand Distance Vector (AODV).

Permasalahan yang muncul adalah ketika menentukan penggunaan jalur yang efisien bahwa link - link antar node masih saling berhubungan dalam pengiriman paket data dari node sumber ke node tujuan.
Penilitian yang akan dibuat dengan melihat permasalahan yang ada adalah dengan cara efisiensi pencarian rute diantara node yang tidak mebebani link. Penerapan analisis efisiensi menggunakan simulasi jaringan komputer dengan menggunakan tools network simulator 2 dimana tingkat performansi dapat diketahui melalui pengukuran nilai parameter average End-to-end delay, energy, dan packet delivery ratio $(P D R)$. Maka dari itu penulis akan melakukan penilitian yang berjudul "Efisiensi rute pada protokol routing Ad Hoc On-Demand Distance Vector (AODV) dengan menggunakan metode Path Aware-Short”.

\subsection{Rumusan Masalah}


INDEXIA: Informatic and Computational Intelegent Journal

Saiful Hamim, Misbah, Nuniek Fahriani

Efisiensi Rute Pada Routing Aodv Menggunakan Algoritma Path Aware Short

Bagaimana cara menerapkan algoritma path aware short pada routing AODV di jaringan MANET?

\subsection{Tujuan Penelitian}

Adapun tujuan dari penelitian ini adalah untuk mendapatkan hasil kinerja efisiensi rute pada routing protokol AODV.

\section{Landasan Teori}

\subsection{Mobile Ad Hoc Network (MANET)}

MANET adalah autonomous system dari node mobile yang terhubung secara nirkabel. Setiap node beroperasi tidak hanya sebagai end system, tetapi juga sebagai router untuk meneruskan paket (Thakare AN, Joshi MY, 2012).

Topologi jaringan MANET dapat berubah dengan cepat dan tak terduga dari waktu ke waktu, karena node bersifat mobile. Tipe network dalam MANET adalah desentralisasi, dimana semua aktivitas jaringan, termasuk menemukan topologi dan penyampaian pesan harus dijalankan oleh node itu sendiri. Oleh karena itu fungsi routing harus dimasukkan ke dalam node mobile (Thakare AN, Joshi MY, 2012). Pada gambar 2.1 menunjukkan jaringan MANET sederhana :

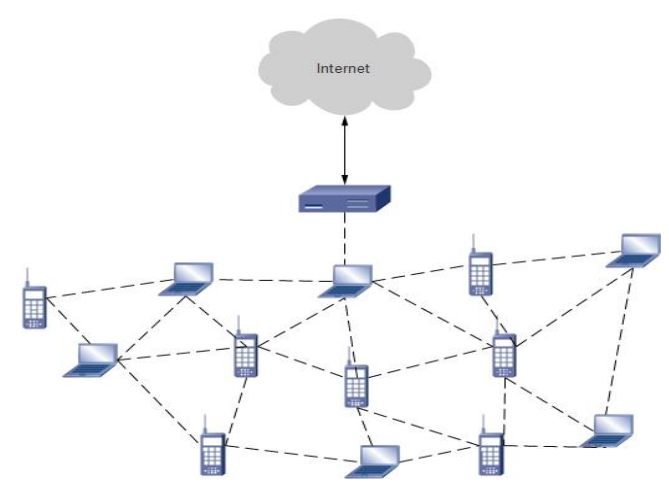

Gambar 2.1 MANET (Abdalla., 2008).

\subsection{Ad Hoc On Demand Distance Vector (AODV)}

AODV merupakan protokol routing yang bersifat reaktif. Protokol ini bersifat reaktif karena protokol ini mulai bekerja saat ada permintaan dari source node untuk mencari tahu jalur-jalur yang akan digunakan untuk mengirimkan pesan ke node tujuan. AODV akan berusaha untuk menemukan jalur yang tidak ada loop dan menemukan jalur terpendek untuk menuju node tujuan (Harahap E. H., 2014). Terdapat dua pesan dalam proses pembentukan rute atau route discovery process pada routing AODV yaitu dengan menggunakan route request (RREQ) dan route reply (RREP). Pada proses route maintenance terdapat satu pesan yaitu route error (RRER) yang dimana apabila terjadi rute eror maka node akan menyebarkan pesan tersebut sampai ke node sumber dan akan melakukan route discovery kembali.

Gambar 2.2 Mekanisme Protokol

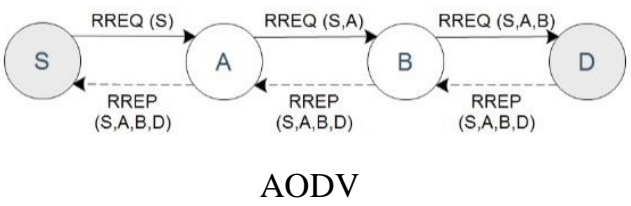

\subsection{Path-Aware Short}

Jalur yang dihasilkan protokol pengaturan rute yang dibutuhkan dapat menyimpang jauh dari jalur terpendek. Karena mobilitas nodenode, bentuk jalur pengaturan rute dapat secara signifikan saat konektivitas utuh. Perubahan bentuk dapat dieksploitasi untuk mendapatkan jalur-jalur pengaturan rute yang lebih baik jika dapat menghindari setiap overhead yang signifikan (setidaknya menghindari prosesproses penemuan path ekstra). 
INDEXIA: Informatic and Computational Intelegent Journal

Saiful Hamim, Misbah, Nuniek Fahriani

Efisiensi Rute Pada Routing Aodv Menggunakan Algoritma Path Aware Short

Gambar 2.3 Perubahan jalur pengaturan rute (Fahriani N, Djanali S, Shiddiqi AM, 2012).

Perhatikan jalur pengaturan rute dari node sumber A kenode tujuan I seperti yang ditunjukkan Gambar 2.3 (a). jalur awal ini ditentukan melalui proses penemuan jalur, dimana jarak antara sumber dan tujuan adalah jarak terpendek menurut jumlah hop. Paket membutuhkan 8 hop saat bergerak dari A ke I. selama perjalanan waktu, mobilitas node dapat membuat bentuk jalur pengaturan rute menjadi seperti Gambar 2.3 (b) saat berusaha mempertahankan konektivitas. Dalam bentuk baru ini, $\mathrm{J}$ ada dalam tingkatan transmisi $\mathrm{F}$. penggunaan cache rute dan validitas informasitentang pengaturan rute pada entri tabel pengaturan rute tidak diupdate. Idealnya, jalur terpendek dari $\mathrm{A}$ ke $\mathrm{H}$ hanya membutuhkan hop seperti yang ditunjukkan Gambar 2.3 (c).

\section{Analisis Dan Perancangan Sistem 3.1 Analisis Sistem}

Rute merupakan salah satu kunci penting dalam jaringan MANET karena sifatnya yang sangat dinamis. Mobilitas host bisa menyebabkan sering terjadinya perubahan topologi yang tidak bisa diprediksi. Proses penemuan rute sering kali membanjiri jaringan dengan paket permintaan rute untuk mencari rute di seluruh jaringan. Hal ini dapat mengakibatkan delay yang tinggi untuk mencapai jalur. Parameter yang mempengaruhi kinerja protokol penentuan rute jaringan ad hoc adalah beberapa node di dalam area, perilaku node yang mengubah konektivitas (bergerak secara bebas sebagai kelompok, frekuensi perubahan topologf), dan kublitas link. Rancangan strategi penentuan rute yang efisien dan reliabefimemang RRerupakan masalah yang

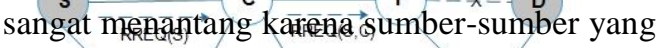
sangat terbatas di dalam MANET (Fahriani N, Djanali S,BShiddiqi AM,E2012). J

\subsection{Hasil Analisis}

Dengan melihat kinerja routing AODV yang dalam pembentukan rute membutuhkan waktu yang cukup lama adalah dengan cara efisiensi pencarian rute diantara node yang tidak membebani link. Oleh sebab itu untuk mendukung informasi optimasi link-link yang menyusun rute digunakan algoritma Path Aware Short dengan memastikan bahwa link yang akan dilalui dalam kondisi baik dan pencarian rute yang paling optimum dengan parameter waktu tempuh yang paling minimal sehingga tidak perlu melakukan proses pengiriman paket route request (RREQ) ulang.

Hasil proses efisiensi akan dilakukan dengan menggunakan tools network simulator 2 dimana tingkat performansi akan dibandingkan nilai parameter average End-toend delay, normalized routing load, dan packet delivery ratio (PDR)antara routing AODV dengan routing AODV yang sudah dimodifikasi dengan algoritma path aware short.

\subsection{Algoritma Routing AODV}

AODV merupakan protokol routing yang bersifat reaktif. Protokol ini bersifat reaktif karena protokol ini mulai bekerja saat ada permintaan dari source nodeuntuk mencari tahu jalur-jalur yang akan digunakan untuk mengirimkan pesan ke node tujuan. AODV akan berusaha untuk menemukan jalur yang tidak ada loop dan menemukan jalur terpendek untuk menuju node tujuan (Harahap EH, 2014). 
INDEXIA: Informatic and Computational Intelegent Journal

Saiful Hamim, Misbah, Nuniek Fahriani

Efisiensi Rute Pada Routing Aodv Menggunakan Algoritma Path Aware Short

Gambar 3.1 Contoh AODV

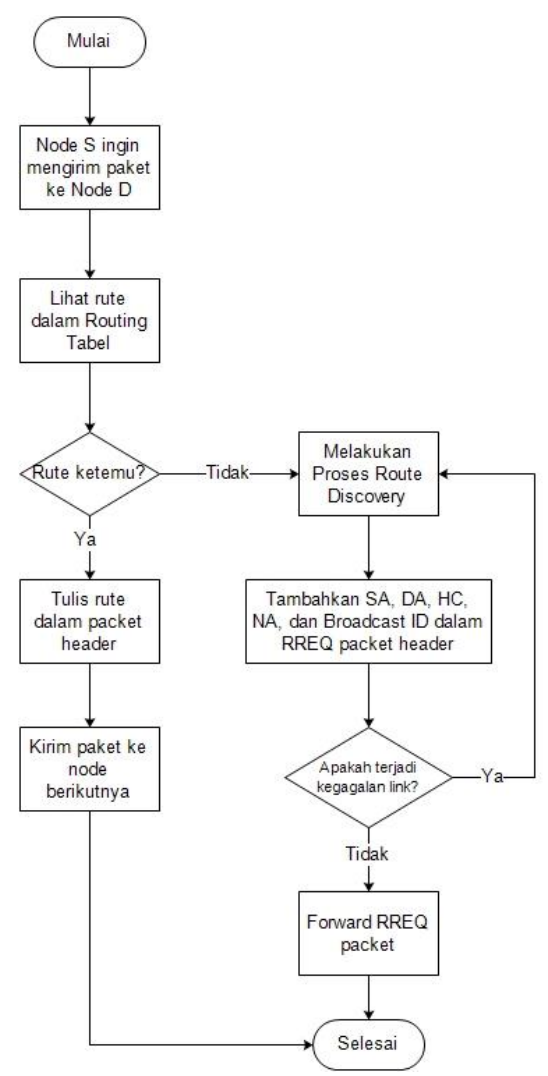

Gambar 3.2 Flowchart routing AODV.

Berikut penjelasan gambar 3.2:

1. Dimulai ketika node $\mathrm{S}$ (source) ingin mengirimkan paket ke node D (Destination).

2. Lihat dalam routing cache apakah ada rute menuju node $\mathrm{D}$ apa tidak.

3. Jika ada maka node $\mathrm{S}$ akan menuliskan rute kedalam packet header dan paket akan langsung dikirimkan ke node $\mathrm{D}$.

4. Jika tidak ada rute menuju node $\mathrm{D}$ maka akan melakukan proses route discovery dan node $\mathrm{S}$ akan membroadcast paket route request (RREQ) ke node tetangga.

5. Pada RREQ paket header ditambahkan SA (source addres), DA (destination addres), HC (hop count), NA (neighbor addres), dan Broadcast ID.
6. Apakah terjadi kegagalan link, jika ada sebuah link antar node terputus maka akan melakukan proses route discovery ulang. Mengulangi langkah nomer 4.

Jika tidak ada kegagalan link antar node maka paket RREQ diteruskan sampai ke node D.

\subsection{AODV Dengan Algoritma Path-Aware Short}

Modifikasi yang dilakukan pada protokol AODV adalah dengan melakukan perubahan pada proses route discovery dan route maintenance. Dengan dilakukan efisiensi adanya kegagalan link di dalam pembentukan rute dengan mengontrol delay. Pada gambar 3.3 algoritma AODV yang telah dimodifikasi dengan menggunakan Algoritma Path Aware Short akan dinamakan dengan PA-AODV.

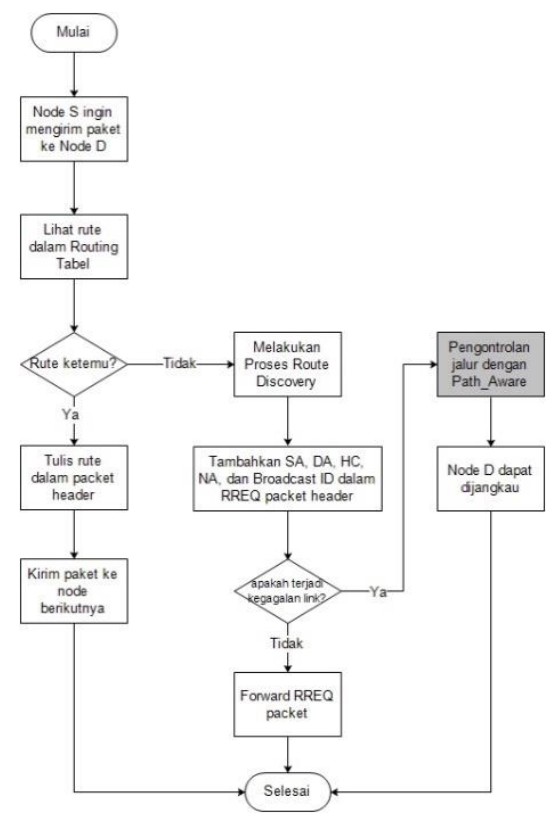

Gambar 3.3 Flowchart PA-AODV

Penjelasan gambar 3.3:

1. Algoritma PA-AODV dimulai dari node $\mathrm{S}$ (source) yang akan mengirim paket ke node $\mathrm{D}$ (destination).

2. Route table akan dicek terlebih dahulu apakah rute sudah ada atau belum. 
INDEXIA: Informatic and Computational Intelegent Journal

Saiful Hamim, Misbah, Nuniek Fahriani

Efisiensi Rute Pada Routing Aodv Menggunakan Algoritma Path Aware Short

3. Jika rute sudah ada maka node $\mathrm{S}$ akan menuliskan rute tujuan kedalam packet header, dan akan langsung dikirim ke node D.

4. Jika node $\mathrm{S}$ belum memiliki rute menuju node $\mathrm{D}$ maka akan melakukan proses route discovery.

5. Node $\mathrm{S}$ akan melakukan broadcast sebuah paket route request (RREQ) ke node tetangganya.

6. Pada RREQ paket header ditambahkan SA (source addres), DA (destination addres), HC (hop count), NA (neighbor addres), dan Broadcast ID.

7. Pada saat pengiriman RREQ apakah terjadi kegagalan link, jika tidak ada kegagalan link maka paket akan diteruskan sampai ke node $\mathrm{D}$.

8. Apabila terjadi kegagalan link makanode $\mathrm{S}$ akan memonitor rute berikutnya dengan Algoritma Path-Aware, yaitu mekanisme pengontrolan jalur sehingga node berikutnya dapat terjangkau dan bisa untuk dilewati. Dimana node disekitarnya akan mencari rute alternatif untuk meneruskan paket yang dikirim dengan delay time terkecil.

Untuk mendukung algoritma Path-Aware yang diajukan, setiap paket membawa bidang hop-count (HC) dalam headernya. HC field diawali dengan nol di node sumber dan ditingkatkan satu di setiap hop yang diambil paket. Untuk setiap paket, alamat tujuan (DA), alamat sumber (SA), dan HC dapat diperoleh dari packet header. Informasi ini disimpan sebagai suatu kesatuan ,emurut kesatuan perbandingan hop. Format setiap entry dalam kesatuan adalah $\langle$ SA, DA, HC, NA $>$, dimana NA adalah alamat tetangga tempat paket disiarkan. Sebelum SA mengirim paket ke node hop pertama, entry berikut informasi dimasukkan dalam kesatuan perbandingan hop SA: $\langle\mathrm{SA}, \mathrm{DA}, 0, \mathrm{SA}\rangle$. Dapat dilihat pada gambar 3.4. Algoritma Path Aware-Short.

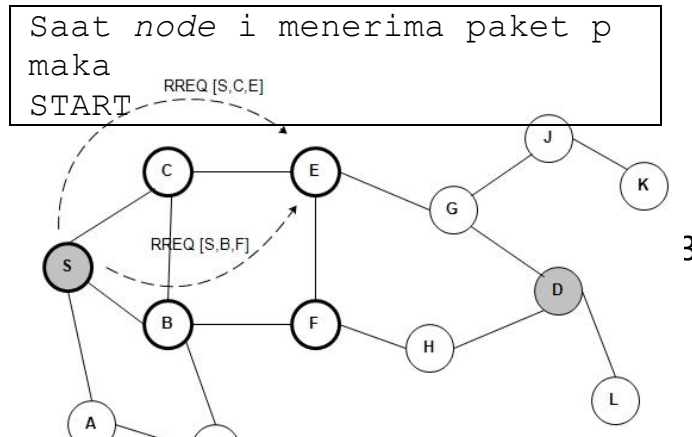

a. Jika node i adalah DA (destination addres), paket dikonsumsi

b. Bandingkan SA (source address) dan DA dari semua entry dalam kesatuan perbandingan hop

c. Jika tidak ada kesesuaian entry, simpan SA, DA, HC (hop count), dan NA (neighbor address) dalam kesatuan perbandingan hop

d. Jika paket ditujukan ke i sebagai node hop

berikutnya, proses paket untuk forwarding.

e. Jika sesuai dengan entry (SA, DA, HC, NA) berarti node i melakukan:

- Mengirim pesan ke NA untuk mengupdate tabel pengaturan rute alamat hop berikutnya untuk node tujuan (DA)

END

Gambar 3.4 Algoritma Path Aware-Short (Fahriani N, Djanali S, Shiddiqi AM, 2012).

Berikut proses route discovery untuk mendapatkan efisiensi rute (Fahriani N, Djanali S, Shiddiqi AM, dkk, 2012). :

1. Sebuah node $\mathrm{S}$ (source) akan mengirim paket ke node $\mathrm{D}$ (destination) pada sebuah MANET. Bila $S$ tidak mengetahui rute menuju $\mathrm{D}, \mathrm{S}$ akan melakukan route discovery. Proses route discovery dilakukan dengan melakukan flooding paket RREQ oleh $\mathrm{S}$.

2. Node intermediate $\mathrm{i}$ (selain node $\mathrm{S}$ dan $\mathrm{D}$ ) yang menerima RREQ akan

a. Memeriksa node yang telah dilalui paket RREQ. Jika RREQ pernah singgah di i, maka RREQ akan di drop karena terjadi pergeseran.

b. Sebelum memforward RREQ, node $\mathrm{i}$ menyisipkan identifiernya pada RREQ yang menandakan RREQ tersebut pernah singgah di i. 
INDEXIA: Informatic and Computational Intelegent Journal

Saiful Hamim, Misbah, Nuniek Fahriani

Efisiensi Rute Pada Routing Aodv Menggunakan Algoritma Path Aware Short

Gambar 3.5 ilustrasi aturan forwarding oleh node intermediate

3. Node destination $\mathrm{D}$ yang menerima RREQ akan membalas dengan mengirim route reply (RREP).

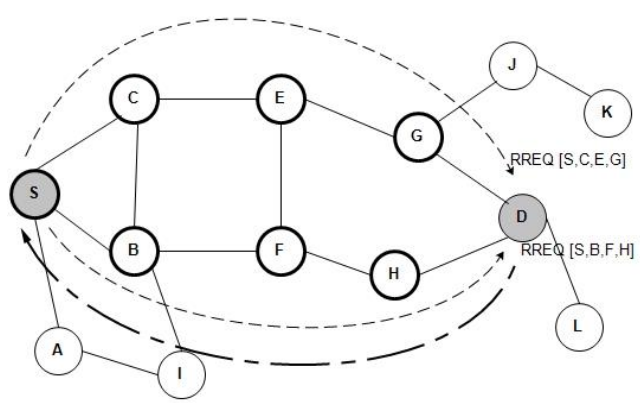

Gambar 3.6 ilustrasi aturan pengiriman RREP oleh node destination.

4. Node source $\mathrm{S}$ yang menerima beberapa RREP akan memilih rute yang efisien.

\subsection{Perancangan Parameter Simulasi}

Dalam melakukan proses simulasi perlu digunakan parameter-parameter untuk menghasilkan hasil sesuai dengan kebutuhan.Pada tabel 3.1 di tunjukkan parameter dan skenario yang digunakan untuk simulasi dengan menggunakan Network Simulator 2.30.

Tabel 3.1 Parameter dan Skenario

\begin{tabular}{|l|c|}
\hline \multicolumn{2}{|c|}{ Parameter dan Skenario } \\
\hline Tipe parameter & Nilai Parameter \\
\hline Packet rate & 1 Packet/s \\
\hline Transmisi range & $250 \mathrm{~m}$ \\
\hline Mac layer & 802.11 \\
\hline
\end{tabular}

\begin{tabular}{|l|c|}
\hline Jumlah node & 50 node, 100 node \\
\hline Network area & $\begin{array}{r}500 \times 500 \mathrm{~m}^{2}, 1000 \mathrm{x} \\
1000 \mathrm{~m}^{2}, 1000 \mathrm{x} \\
1500 \mathrm{~m}^{2}\end{array}$ \\
\hline Waktu simulasi & $5.0 \mathrm{~s}$ \\
\hline Mobility model & Random Waypoint \\
\hline Propagation & Two Ray Ground \\
\hline Maximum speed & $10 \mathrm{~m} / \mathrm{s}$ \\
\hline Pola trafik & CBR \\
\hline Packet size & $512 \mathrm{byte}$ \\
\hline
\end{tabular}

\subsection{Parameter Pengukuran}

Berikut adalah beberapa parameter yang digunakan dalam menguji kinerja PAAODV terhadap AODV yaitu (Fahriani, N., dkk, 2012):

\section{Packet Delivery Ratio}

Packet delivery ratio (PDR) adalah rasio antara banyaknya paket yang diterima oleh tujuan dengan banyaknya paket yang dikirim oleh sumber. Berikut rumus untuk menghitung PDR:

$$
\begin{aligned}
& \text { Packet Delivery Ratio (\%) } \\
& =\frac{\sum \text { paket data yang diterima }}{\sum \text { paket data yang dikirim }} \times 100 \%
\end{aligned}
$$

\section{Average end-to-end delay}

Average end-to-end delay adalah jeda waktu antara paket pertama dikirim dengan paket tersebut diterima. Berikut rumus untuk menghitung Average end-to-end delay :

$$
\begin{aligned}
& \text { Average Delay }(\mathrm{m} / \mathrm{s}) \\
& =\frac{\text { total delay }}{\text { total paket yang diterima }} \\
& \text { Dimana } \\
& \text { delay }=\text { Received time } \\
& - \text { Sent time }
\end{aligned}
$$

3. Energy 
INDEXIA: Informatic and Computational Intelegent Journal

Saiful Hamim, Misbah, Nuniek Fahriani

Efisiensi Rute Pada Routing Aodv Menggunakan Algoritma Path Aware Short

Energy adalah energy yang digunakan oleh node untuk berinteraksi dan mengirimkan paket ke semua node.

\section{Implementasi dan Pengujian Sistem 4.1 Implementasi Sistem}

Implementasi dan pengujian sistem routing protokol AODV dan Path Aware AODV menggunakan simulasi dengan software Network Simulator 2 versi 2.35. Berikut ini merupakan parameter dan skenario pengujian dengan transmisi range $250 \mathrm{~m}$, model antena menggunakan Omni Antena dengan trafik CBR, ukuran paket sebesar 100 byte dengan waktu simulasi 180 detik.

\subsection{Pengujian Sistem}

Setelah dilakukan implementasi sistem, selanjutnya yaitu dilakukan pengujian sistem dengan melakukan pembuatan skenario.

\section{Ad Hoc On-Demand Distance Vector (AODV)}

a. Analisa 50 Node dengan dimensi topologi X $500 \mathrm{~m}^{2}$ dan Y $500 \mathrm{~m}^{2}$

Hasil simulasi yang didapatkan pada Analisa 50 Node dengan dimensi topologi X $500 \mathrm{~m}^{2}$ dan Y $500 \mathrm{~m}^{2}$ yaitu konsumsi energy 20.8521, packet delivery ratio 100 , average end-to-end delay 57.2865 .

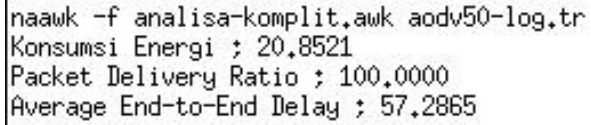

Gambar 4.1 Hasil Analisa AWK AODV 50 Node dengan dimensi topologi X 500 $\mathrm{m}^{2}$ dan Y $500 \mathrm{~m}^{2}$

b. Analisa 50 Node dengan dimensi topologi X $1000 \mathrm{~m}^{2}$ dan Y $1000 \mathrm{~m}^{2}$

Hasil simulasi yang didapatkan pada Analisa 50 Node dengan dimensi topologi X $1000 \mathrm{~m}^{2}$ dan Y $1000 \mathrm{~m}^{2}$ yaitu konsumsi energy 17.4097, packet delivery ratio 100 , average end-to-end delay 60.4679 .

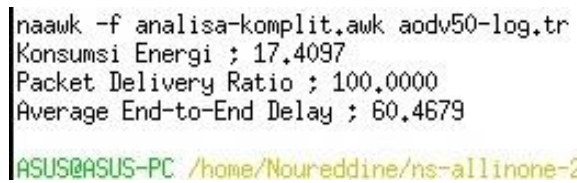

Gambar 4.2 Hasil Analisa AWK AODV 50 node dengan dimensi topologi X $1000 \mathrm{~m}^{2}$ dan Y $1000 \mathrm{~m}^{2}$.

c. Analisa 50 Node dengan dimensi topologi X $1000 \mathrm{~m}^{2}$ dan Y $1500 \mathrm{~m}^{2}$

Hasil simulasi yang didapatkan pada Analisa 50 Node dengan dimensi topologi X $1000 \mathrm{~m}^{2}$ dan Y $1500 \mathrm{~m}^{2}$ yaitu konsumsi energy 11.8603 , packet delivery ratio 97.2973 , average end-toend delay 599.6042.

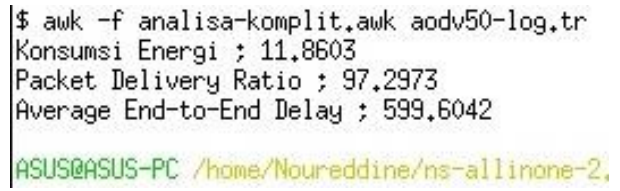

Gambar 4.3 Hasil Analisa AWK AODV 50 node dengan dimensi topologi X $1000 \mathrm{~m}^{2}$ dan Y $1500 \mathrm{~m}^{2}$.

d. Analisa 100 Node dengan dimensi topologi X $500 \mathrm{~m}^{2}$ dan Y $500 \mathrm{~m}^{2}$

Hasil simulasi yang didapatkan pada Analisa 100 Node dengan dimensi topologi X $500 \mathrm{~m}^{2}$ dan Y $500 \mathrm{~m}^{2}$ yaitu konsumsi energy 46.9472, packet delivery ratio 100 , average end-to-end delay 6.6018 .

\$ awk -f analisa-komplit,auk aodv100-log,tr Konsumsi Energi : 46, 9472

Packet Delivery Ratio : 100,0000

Average End-to-End Delay ; 6,6018

ASUS@ASUS-PC /home/Noureddine/ns-allinone-2,35

Gambar 4.4 Hasil Analisa AWK AODV 100 node dengan dimensi topologi $\mathrm{X} 500 \mathrm{~m}^{2}$ dan Y $500 \mathrm{~m}^{2}$.

e. Analisa 100 Node dengan dimensi topologi X $1000 \mathrm{~m}^{2}$ dan Y $1000 \mathrm{~m}^{2}$

Hasil simulasi yang didapatkan pada Analisa 100 Node dengan dimensi topologi X $1000 \mathrm{~m}^{2}$ dan Y $1000 \mathrm{~m}^{2}$ yaitu konsumsi energy 22.2253, packet delivery ratio 95.8333 , average end-toend delay 6.6590. 
INDEXIA: Informatic and Computational Intelegent Journal

Saiful Hamim, Misbah, Nuniek Fahriani

Efisiensi Rute Pada Routing Aodv Menggunakan Algoritma Path Aware Short

\$ awk -f analisa-komplit,awk aodv100-log,tr

Konsumsi Energi : 22.2253

Packet Delivery Ratio : 95,8333

Average End-to-End Delay ; 6.6590

ASUSeASUS-PC /home/Noureddine/ns-allinone-2.

Gambar 4.5 Hasil Analisa AWK AODV 100 node dengan dimensi topologi $\mathrm{X} 1000 \mathrm{~m}^{2}$ dan Y $1000 \mathrm{~m}^{2}$.

f. Analisa 100 Node dengan dimensi topologi X $1000 \mathrm{~m}^{2}$ dan Y $1500 \mathrm{~m}^{2}$

Hasil simulasi yang didapatkan pada Analisa 100 Node dengan dimensi topologi X $1000 \mathrm{~m}^{2}$ dan Y $1500 \mathrm{~m}^{2}$ yaitu konsumsi energy 46.9472, packet delivery ratio 100 , average end-to-end delay 6.6018 .

$\$$ awk - $f$ analisa-komplit, awk aodv100-log,tr Konsumsi Energi : 46,9472

Packet Delivery Ratio : 100,0000

Average End-to-End Delay ; 6.6018

ASUS@ASUS-PC /home/Noureddine/ns-allinone-2.35

Gambar 4.6 Hasil Analisa AWK AODV 100 node dengan dimensi topologi $X 1000 \mathrm{~m}^{2}$ dan Y $1500 \mathrm{~m}^{2}$.

\section{Path Aware Ad Hoc On-Demand Distance Vector (PAODV)}

a. Analisa 50 Node dengan dimensi topologi X $500 \mathrm{~m}^{2}$ dan Y $500 \mathrm{~m}^{2}$

Hasil simulasi yang didapatkan pada Analisa 50 Node dengan dimensi topologi X $500 \mathrm{~m}^{2}$ dan Y $500 \mathrm{~m}^{2}$ yaitu konsumsi energy 16.6054, packet delivery ratio 31.9820 , average end-toend delay 11.5329.

\$ awk -f analisa-komplit,auk paodu50,tr Konsumsi Energi : 16,6054

Packet Delivery Ratio : 31,9820

Average End-to-End Delay : 11.5329

ASUSBASUS-PC /home/Noureddine/ns-allinone-

Gambar 4.7 Hasil Analisa AWK

PAODV 50 Node dengan dimensi topologi X $500 \mathrm{~m}^{2}$ dan Y $500 \mathrm{~m}^{2}$

b. Analisa 50 Node dengan dimensi topologi X $1000 \mathrm{~m}^{2}$ dan Y $1000 \mathrm{~m}^{2}$

Hasil simulasi yang didapatkan pada Analisa 50 Node dengan dimensi topologi X $1000 \mathrm{~m}^{2}$ dan Y $1000 \mathrm{~m}^{2}$ yaitu konsumsi energy 100, packet delivery ratio 30.5439 , average end-toend delay 12.8235 .

ASUS[ASUS-PC /home/Noureddine/ns-allinone-

$1-1000 \times 1000$

$\$$ awk - $f$ analisa-komplit,awk paodu50,tr

Konsumsi Energi : 100,0000

Packet Delivery Ratio : 30.5439

Average End-to-End Delay : 12,8235

Gambar 4.8 Hasil Analisa AWK PAODV 50 node dengan dimensi topologi X $1000 \mathrm{~m}^{2}$ dan Y $1000 \mathrm{~m}^{2}$.

c. Analisa 50 Node dengan dimensi topologi X $1000 \mathrm{~m}^{2}$ dan Y $1500 \mathrm{~m}^{2}$

Hasil simulasi yang didapatkan pada Analisa 50 Node dengan dimensi topologi X $1000 \mathrm{~m}^{2}$ dan Y $1500 \mathrm{~m}^{2}$ yaitu konsumsi energy 100, packet delivery ratio 86.9048 , average end-toend delay 13.3939.

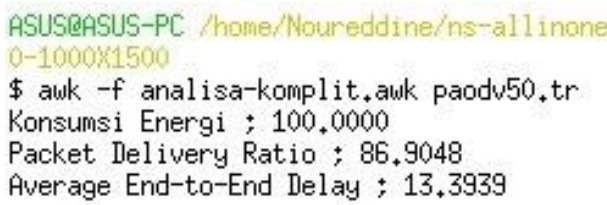

Gambar 4.9 Hasil Analisa AWK PAODV 50 node dengan dimensi topologi X $1000 \mathrm{~m}^{2}$ dan Y $1500 \mathrm{~m}^{2}$.

d. Analisa 100 Node dengan dimensi topologi X $500 \mathrm{~m}^{2}$ dan Y $500 \mathrm{~m}^{2}$

Hasil simulasi yang didapatkan pada Analisa 100 Node dengan dimensi topologi X $500 \mathrm{~m}^{2}$ dan Y $500 \mathrm{~m}^{2}$ yaitu konsumsi energy 100, packet delivery ratio 69.5238 , average end-toend delay 5.1087.

ASUS@ASUS-PC /home/Noureddine/ns-allinone$00-500 \times 500$

\$ auk - $f$ analisa-komplit awk paodv100,tr

Konsumsi Energi : 100,0000

Packet Delivery Ratio : 69.5238

Average End-to-End Delay ; 5.1087

Gambar 4.10 Hasil Analisa AWK PAODV

100 node dengan dimensi topologi X $500 \mathrm{~m}^{2}$ dan Y $500 \mathrm{~m}^{2}$.

e. Analisa 100 Node dengan dimensi topologi X $1000 \mathrm{~m}^{2}$ dan Y $1000 \mathrm{~m}^{2}$

Hasil simulasi yang didapatkan pada Analisa 100 Node dengan dimensi topologi X $1000 \mathrm{~m}^{2}$ dan Y $1000 \mathrm{~m}^{2}$ yaitu konsumsi energy 
INDEXIA: Informatic and Computational Intelegent Journal

Saiful Hamim, Misbah, Nuniek Fahriani

Efisiensi Rute Pada Routing Aodv Menggunakan Algoritma Path Aware Short

10.7898, packet delivery ratio 73.9583 , average end-to-end delay 9.8217.

\section{ASUS@ASUS-PC /home/Noureddine/ns-allinone- \\ \$ awk - $f$ analisa-komplit, awk paodv100,tr Konsumsi Energi : 10.7898 \\ Packet Delivery Ratio : 73,9583 \\ Average End-to-End Delay :9.8217}

Gambar 4.11 Hasil Analisa AWK PAODV 100 node dengan dimensi topologi X $1000 \mathrm{~m}^{2}$ dan Y $1000 \mathrm{~m}^{2}$.

f. Analisa 100 Node dengan dimensi topologi X $1000 \mathrm{~m}^{2}$ dan Y $1500 \mathrm{~m}^{2}$

Hasil simulasi yang didapatkan pada Analisa 100 Node dengan dimensi topologi X $1000 \mathrm{~m}^{2}$ dan Y $1500 \mathrm{~m}^{2}$ yaitu konsumsi energy 17.2748, packet delivery ratio 15.2000 , average end-toend delay 9.4599 .

awk -f analisa-komplit,awk paodv100,tr Konsumsi Energi; 17,2748

Packet Delivery Ratio : 15,2000

Average End-to-End Delay ; 9.4599

\section{ASUSQASUS-PC /home/Noureddine/ns-allinone-}

Gambar 4.12 Hasil Analisa AWK PAODV

100 node dengan dimensi topologi X $1000 \mathrm{~m}^{2}$ dan Y $1500 \mathrm{~m}^{2}$.

\subsection{Analisa hasil Pengujian Sistem}

Hasil performansi jaringan routing protokol AODV dan modifikasi AODV dengan path-aware dengan beberapa analisa sesuai parameter yang ditentukan yaitu packet delivery ratio, average delay, energy adalah sebagai berikut:

a. Parameter average end to end delay

Tabel 4.1 Hasil Simulasi Parameter Average End to End Delay

\begin{tabular}{|c|c|c|c|c|}
\hline $\begin{array}{c}\text { Networ } \\
k \\
\text { Area } \\
\left(\mathbf{m}^{2}\right)\end{array}$ & \multicolumn{3}{|c|}{ Average End to End Delay } \\
\cline { 2 - 5 } & \multicolumn{2}{|c|}{ AODV } & \multicolumn{2}{|c|}{ PAODV } \\
\cline { 2 - 5 } & $\begin{array}{c}50 \\
\text { node }\end{array}$ & $\begin{array}{c}100 \\
\text { node }\end{array}$ & $\begin{array}{c}50 \\
\text { node }\end{array}$ & $\begin{array}{c}100 \\
\text { nod } \\
\text { e }\end{array}$ \\
\hline
\end{tabular}

\begin{tabular}{|c|c|c|c|c|}
\hline $\begin{array}{c}\mathbf{5 0 0 x 5 0} \\
\mathbf{0}\end{array}$ & $\begin{array}{c}57,28 \\
65\end{array}$ & 6.6018 & 11,53 & 5,10 \\
29 & 87 \\
\hline $\begin{array}{c}\mathbf{1 0 0 0 x 1} \\
\mathbf{0 0 0}\end{array}$ & 60,46 & 6.6590 & 12,82 & 9,82 \\
& & & 35 & 17 \\
\hline $\mathbf{1 0 0 0 x 1}$ & 599,6 & 1675,7 & 13,39 & 9,45 \\
$\mathbf{5 0 0}$ & 042 & 164 & 39 & 99 \\
\hline
\end{tabular}

Pada tabel 4.1 menunjukkan hasil simulasi dengan parameter average end to end delay menunjukkan nilai terbaik yaitu pada path aware AODV area network 500x500 dengan 100 node 5,1087, delay yang sedikit membuat pengiriman paket dari node sumber ke node tujuan menjadi lebih cepat.

b. Parameter paket delivery ratio

Tabel 4.2 Hasil simulasi Parameter paket delivery ratio

\begin{tabular}{|c|c|c|c|c|}
\hline \multirow{2}{*}{$\begin{array}{c}\text { Networ } \\
\mathbf{k}\end{array}$} & \multicolumn{3}{|c|}{ Paket Delivery Ratio } \\
\cline { 2 - 5 } $\begin{array}{c}\text { Area } \\
\left(\mathbf{m}^{2}\right)\end{array}$ & \multicolumn{2}{|c|}{ AODV } & \multicolumn{2}{c|}{ PAODV } \\
\cline { 2 - 5 } & $\begin{array}{c}\mathbf{5 0} \\
\text { node }\end{array}$ & $\begin{array}{c}\mathbf{1 0 0} \\
\text { node }\end{array}$ & $\begin{array}{c}\mathbf{5 0} \\
\text { node }\end{array}$ & $\begin{array}{c}\mathbf{1 0 0} \\
\text { node }\end{array}$ \\
\hline $\begin{array}{c}\mathbf{5 0 0 x 5 0} \\
\mathbf{0}\end{array}$ & 100 & 100 & 31.98 & 69.52 \\
& & & 20 & 38 \\
\hline $\begin{array}{c}\mathbf{1 0 0 0 x 1} \\
\mathbf{0 0 0}\end{array}$ & 100 & 95.83 & 30.54 & 73.95 \\
& & 33 & 39 & 83 \\
\hline $\mathbf{1 0 0 0 x 1}$ & 97.29 & 92.85 & 86.90 & 15,20 \\
$\mathbf{5 0 0}$ & 73 & 71 & 48 & 00 \\
\hline
\end{tabular}

Pada tabel 4.2 menunjukkan hasil simulasi dengan parameter paket delivery ratio menunjukkan nilai terbaik pada routing AODV dengan 50 node area 500x500, 100 node area 500x500, 50 node area 1000x1000 dengan nilai 100. Semakin banyak nilai PDR menunjukkan berapa banyak paket yang sukses terkirim ke node tujuan.

c. Parameter konsumsi energy

Tabel 4.3 Hasil simulasi Parameter konsumsi energy 


\begin{tabular}{|c|c|c|c|c|}
\hline $\begin{array}{c}\text { Networ } \\
\mathbf{k}\end{array}$ & \multicolumn{2}{|c|}{ AODV } & \multicolumn{2}{c|}{ PAODV } \\
\cline { 2 - 5 } $\begin{array}{c}\text { Area } \\
\left(\mathbf{m}^{\mathbf{2}}\right)\end{array}$ & $\begin{array}{c}\mathbf{5 0} \\
\text { node }\end{array}$ & $\begin{array}{c}\mathbf{1 0 0} \\
\text { node }\end{array}$ & $\begin{array}{c}\mathbf{5 0} \\
\text { node }\end{array}$ & $\begin{array}{c}\mathbf{1 0 0} \\
\text { node }\end{array}$ \\
\hline $\begin{array}{c}\mathbf{5 0 0 x 5 0} \\
\mathbf{0}\end{array}$ & 20.85 & 46.94 & 16.60 & 100 \\
\hline $\begin{array}{c}\mathbf{1 0 0 0 x 1} \\
\mathbf{0 0 0}\end{array}$ & 17.40 & 22.22 & 100 & 10.78 \\
& 97 & 53 & & 98 \\
\hline $\begin{array}{c}\mathbf{1 0 0 0 x 1} \\
\mathbf{5 0 0}\end{array}$ & 11.86 & 10.77 & 100 & 17.27 \\
& & 94 & & 48 \\
\hline
\end{tabular}

Pada tabel 4.3 menunjukkan hasil simulasi parameter konsumsi energy menunjukkan penggunaan energy paling sedikit yaitu pada protokol routing AODV dengan 100 node area 1000x1500 dengan nilai 10,7794, semakin sedikit energy yang digunakan oleh node maka akan memungkinkan untuk node bertahan lebih lama dalam pengiriman paket.

\section{Penutup}

\subsection{Kesimpulan}

Skripsi ini menghasilkan beberapa kesimpulan sebagai berikut:

1. efisiensi rute menggunakan path aware short mengalami keberhasilan dengan parameter average end to end delay untuk 100 node dengan network area $500 \mathrm{~m}^{2}$ x $500 \mathrm{~m}^{2}$ yaitu $5,1087 \mathrm{~m} / \mathrm{s}$.

2. Karena selang waktu yang dibutuhkan lebih pendek dan tidak membebani link (kemungkinan kecil terputus). Dampak yang didapat dari efisiensi delay mengakibatkan semakin banyak paket RREQ yang dikirim, mengakibatkan peluang tabrakan antar paket semakin besar, menyebabkan hilangnya paket data yang drop, dikarenakan node pengirim akan lebih banyak melakukan broadcast paket routing pada proses route discovery (RREQ dan RREP) untuk mendapatkan rute yang baru. Dapat dilihat pada parameter packet delivery ratio nilai terbaik pada routing AODV dengan 50 node area 500x500,
100 node area 500x500, 50 node area 1000x1000 dengan nilai $100 \%$.

3. Untuk parameter energy yang sedikit dalam konsumsi energy yaitu pada protokol routing AODV dengan 100 node area $1000 \times 1500$ dengan nilai 10,7794 joule.

\subsection{Saran}

Saran penulis terhadap skripsi ini adalah sebagai berikut:

1. Melakukan penelitian menggunakan protokol routing yang lain pada jaringan MANET.

2. Melakukan penelitian menggunakan protokol routing yang sama dengan parameter simulasi yang berbeda dan dengan algoritma yang berbeda.

3. Melakukan perbaikan parameter nilai untuk packet delivery ratio.

\section{Daftar Pustaka}

Abdalla H. Simulation on Multipath Routing Based On Source Routing, Bachelorarbeit, University of Bern; 2008.

Arifin M, Hadi ZS, Amran H, Nuansa PR. Analisis Performansi Routing AODV pada Jaringan VANet. EEPIS. Surabaya: Teknik Telekomunikasi dan Politeknik Elektronika Negeri Surabaya; 2011.

Arinatal YA. Analisis Kecepatan Inisialisasi Jaringan Ad Hoc pada Routing Protocol AODV, OLSR, dan ZRP dengan NS 2. Tugas Akhir. Yogyakarta: Fakultas Sains dan Teknologi Universitas Sanata Dharma; 2015.

Dana A, Zadeh AK, Noori SAS. Backup Path Set Selection in Ad Hoc Wireless Network Using Link Expiration Time, Computers and Electrical Engineering, vol. 34, (hal. 503-519); 2008.

Fahriani N, Djanali S, Shiddiqi AM. Efisiensi rute pada protokol Dynamic Source 
INDEXIA: Informatic and Computational Intelegent Journal

Saiful Hamim, Misbah, Nuniek Fahriani

Efisiensi Rute Pada Routing Aodv Menggunakan Algoritma Path Aware Short

Routing menggunakan Path AwareShort. Eksplora informatika Vol. 2 No. 1 (hal. 37-48). Surabaya: Institut Teknologi Sepuluh November; 2012.

Harahap EH. Analisis Performansi Protokol AODV (Ad hoc On Demand Distance Vector) dan DSR (Dynamic Source Routing) terhadap Active Attack pada MANET (Mobile Ad hoc Network) ditinjau dari QoS (Quality of Service) Jaringan. E-Proceeding of Engineering Vol. 1 No. 1 (hal. 118126). Teknik Telekomunikasi dan Universitas Telkom; 2014.

Permana MY, Purwanto Y, Wahida I. Analisis pengaruh penggunaan protokol routing AODV, DSDV, dan ZRP pada performansi jaringan Ad hoc Hibrid. Tugas Akhir; 2010.

Putranto ATS. Analisis Penggunaan Energi AODV dan DSDV pada Mobile Ad Hoc Network. Jurusan Teknik Informatika Fakultas Sains dan Teknologi Universitas Sanata Dharma, Yogyakarta; 2016.

Purba DU, Primananda R, Amron K. Analisis Kinerja Protokol Ad Hoc OnDemand Vector (AODV) dan Fisheye State Routing (FSR) pada Mobile Ad Hoc Network. Jurnal Pengembangan Teknologi Informasi dan Ilmu Komputer Vol. 2, No. 7 (Hal. 2626-2636). Universitas Brawijaya; 2017.

Rudhyanto PF. Analisis Perbandingan Unjuk Kerja Protokol Proaktif DSDV Terhadap Protokol Routing Reaktif DSR Pada Jaringan MANET. Program Studi Teknik Informatika, Fakultas Sains dan Teknologi Universitas Sanata Dharma, Yogyakarta; 2016.

Srinivasan P, Kamalakkannan P. RSEAAODV: Route Stability and Energy Aware Routing for Mobile Ad Hoc Networks. International Journal of
Computers Communications \& Control Vol. 8, No. 6 (hal. 891-900). Tamil Nadu: Mahendra Institute of Technology, Namakkal; 2013.

Sugianto DR. Perbandingan Kecepatan Konvergensi Tabel routing Protokol Dymo dan AODV pada Mobile Ad Hoc Network dengan Simulator NS 2. Tugas Akhir. Yogyakarta: Fakultas Sains dan Teknologi Universitas Sanata Dharma; 2013.

Thakare AN, Joshi MY. Performance Analysis of AODV \& DSR Routing Protocol in Mobile Ad Hoc Networks. Departement of Computer Engineering. Nagpur: RTm Nagpur University; 2010.

Windianto W, Djanali S, Husni M. Optimasi routing pada protokol AODV_EXT dengan menggunakan Link Expiration Time (LET). Jurnal Ilmiah Teknologi Informasi Vol. 13 No. 2 (hal. 143-151). Surabaya: Fakultas Teknologi Informasi dan Institut Teknologi Sepuluh November; 2015.

Yanuar GC. Analisis Perbandingan Unjuk Kerja Protokol Routing Proaktif B.A.T.M.A.N Terhadap Routing Protokol Proaktif OLSR Pada Jaringan Manet. Jurusan Teknik Informatika Fakultas Sains dan Teknologi Universitas Sanata Dharma, Yogyakarta; 2016. 